Mirna Marković-Pavlovićl

UDK: 159. 9:316]:331.5

\title{
NASTAVAK OBRAZOVANJA U USLOVIMA NEIZVJESNOSTI - ULAZNICA ZA BIRO ZA ZAPOŠLJAVANJE ILI DOBRA MENADŽERSKA STRATEGIJA?
}

\section{- Sažetak -}

Jedna od sve češće naglašavanih interpretacija bosanskohercegovačkog konteksta sugeriše kako visokoobrazovne institucije $i$ tržište rada vode dvije (neprimjereno) odvojene politike. Istovremeno, mladi ljudi vlastitim procjenama rizika i u skladu sa mogućnostima koje im stoje na raspolaganju kroz nastavak obrazovanja nastoje povećati svoje prilike na tržištu rada. Da li je ovo ulaganje (vremena, materijalnih resursa, entuzijazma) zaista svrsishodno ili barem proporcionalno vrijednosti očekivanog ishoda? Čini se da će ova hipoteza prvi put značajnije biti ispitivana kada se pojedinac suoči sa (ne)vjerovatnošću pronalaska zaposlenja u struci, a drugi put kada se suoči sa izazovom očuvanja statusa zaposlenja, jednom kada uđe na tržište rada.

Ključne riječi: nesigurnost posla, mlađi zaposlenici, obrazovni sistem, obuka i trening u radnim organizacijama.

1 Mr. Mirna Marković-Pavlović, viši asistent, Odsjek za psihologiju Filozofskog fakulteta u Sarajevu, Univerzitet u Sarajevu. 


\section{Uvod}

Mladi ljudi u visokoobrazovnim institucijama još u vrijeme kada bi svoje značajne resurse: kognitivne kapacitete i spremnost i želju za obrazovanjem trebali ulagati u krajnje logičnu svrhu - sticanje kompetencija i anticipiranje njihove konkretne primjenjivosti, to ne mogu postići u potpunosti. Ovi budući zaposlenici, valoriziraju vlastite prilike za zapošljavanje nakon završetka obrazovanja i svoje kognitivne resurse dodatno ulažu i u predviđanje mogućih ishoda. Ponekad, njihove procjene o tome bivaju u dobroj mjeri oblikovane stavovima značajnih drugih (kolega, prijatelja, roditelja) i njihovim iskustvima u pronalasku posla. Stoga i ne čudi kako ne tako optimistične poruke iz okruženja utječu na to da ovi mladi ljudi ponekad gube motivaciju za ulaganje napora u postizanje obrazovnih ciljeva. Ta povremena kriza svrsishodnosti biva uglavnom privremena. Ipak, o tome koliko je ona potencijalno ozbiljna govori činjenica da će se važnost i svrsishodnost obrazovanja i daljneg ulaganja u obuku i trening ponovo preispitivati i na radnom mjestu. Tada će se imati prilika vidjeti da li obuka i trening povećavaju prilike za očuvanje konkretnog posla i da li donose neku drugu, sekundarnu dobit, poput povećanja šanse ovih zaposlenih na tržištu rada nakon eventualnog gubitka trenutnog posla?

U vrijeme kada zaposlenje u budućnosti postaje sve neizvjesnije, a doživljaj zaposlenika o njihovoj nemoći da preveniraju nepovoljne ishode, poput neželjenog gubitka posla, sve intenzivniji, pronalazak efikasnih strategija za suočavanje sa neizvjesnošću postaje pravi izazov. Razina doživljene nesigurnosti posla i kontinuirana kognitivna evaluacija vlastitog radnog iskustva ,zauzimaju,, značajne kognitivne resurse, koji ne mogu istovremeno biti iskorišteni na nekom drugom polju. Zaposlenici su u takvim okolnostima manje fokusirani na izvršavanje radnih zadataka, a više na anticipaciju mogućeg stresnog događaja. To njihovu kognitivnu i bihevioralnu izvedbu postavlja na nižu razinu od optimalne.

U ukolnostima kada bi nosioci stvarnih društvenih promjena, mladi obrazovani ljudi, trebali s lakoćom pronalaziti prilike za opravdavanje vlastitih ulaganja, ali i ulaganja nastavnog osoblja i države u postizanje obrazovnih ciljeva, takve prilike nisu jednostavno dostupne. Može li menadžment u radnoj organizaciji u uslovima opšte neizvjesnosti prepoznati priliku da obrazovanju dâ dodatnu vrijednost ulaganjem napora da svojim zaposlenicima ponudi trening i obuku? Da li je ovo efikasna strategija mudrog rukovođenja? 


\section{Doživljaj nesigurnosti posla kao doživljaj prijetnje realizaciji brojnih funkcija koje rad ima u životu pojedinca}

Da bi se što realnije sagledale vrijednosti koje obrazovanje (obuka i trening) zaposlenih može imati u očuvanju njihove zapošljivosti i povećanju njihovog profesionalnog samopouzdanja, važno je podsjetiti na to koliko značajnu ulogu posao i radno mjesto imaju u životu pojedinca. Taj uvid bi trebao dodatno ukazati na serioznost doživljaja o postojanju mogućnosti gubitka takve vrijednosti - zaposlenja i mogućnosti za unapređenje vlastitih kompetencija.

Razumijevanje značenja ostvarenosti pojedinih aspekatačovjekovogživota, poput njegove radne uloge, predstavlja jasan put ka sagledavanju značenja i ozbiljnosti koju doživljena prijetnja njegovoj realizaciji ili kontinuitetu (npr. nesigurnost u vezi sa kontinuitetom trenutnog zaposlenja) može ostaviti na kognitivnom, konativnom kao i na ponašajnom planu pojedinca.

Pored izuzetno važne ekonomske, rad ima i vrlo važnu socijalnu i psihološku funkciju u životu čovjeka (Šverko, 1991). Rad omogućava socijalnu interakciju, uspostavljanje i razvijanje prijateljstava ili poznanstava, strukturiranje vremena, a predstavlja i izvor društvenog statusa i prestiža. Uz sve to, on predstavlja značajan dio identiteta pojedinca, izvor je njegovog samopoštovanja. Kroz rad i postignuće u radu, pojedinac formira uvjerenja o vlastitoj vrijednosti, a mnogi kroz rad uspijevaju postići ispunjenje vlastitih kreativnih potencijala. Od toga da li je i u kojoj mjeri svaka od ovih funkcija realizirana, zavisit će kvalitet radnog života nekog pojedinca. Pri tome, treba imati na umu kako će stepen realiziranosti svake od funkcija zavisiti od toga do koje mjere karakteristike posla pojedinca i njegovog radnog okruženja omogućavaju ostvarenje ovih funkcija. Sasvim je jasno kako nesigurno okruženje, okruženje koje karakterizira neizvjesnost ishoda, poput npr. radne organizacije koja loše posluje i izložena je pritisku smanjenja broja zaposlenih, kreira nepovoljne percepcije i doživljaj nesigurnosti pojedinca, a koji je istvoremeno povezan sa objektivno lošijim prognozama za postizanje kvalitetnog radnog života u budućnosti.

I dok se pitanju kvaliteta radnog života i zaposlenja danas posvećuje velika pažnja u programima važnih institucija, poput onih koje stoje u okriljima socijalne politike u Evropskoj uniji, njegov status u našoj zemlji posljednjih 20-ak godina je sasvim marginaliziran. Brojne radne organizacije se suočavaju sa pritiscima pravdanja bazne ekonomske isplativosti opstanka, a posljedično sistem vrijednosti mnogih zaposlenih u vrh postavlja sigurnost posla, jer se čini važnijim od bilo čega danas imati posao, pa ostalo tek nakon toga. No, 
ovakva situacija samo je konglomerat brojnih nepovoljnih kretanja, poput rata u $\mathrm{BiH}$ i znakovitog pada ekonomije, ali i odjeka velike ekonomske krize koja je pogodila cijeli svijet. Ratna dešavanja na teritoriji bivše Jugoslavije uništila su industrijske kapacitete, a postratni period svjedoči težak oporavak infrastukture, koja u pojedinim segmentima do ove godine nije uspjela dostići niti prijeratni nivo. S druge strane, nepovoljne promjene na globalnoj ekonomskoj sceni inicirale su nepopularne trendove o kojima je, što prije, potrebno osvijestiti i poslodavce i zaposlenike, kako bi se konstruktivnije sa njima suočavali. Stoga, zabrinutost u vezi sa budućnošću zaposlenja potrebno je staviti u jedan širi koncept nesigurnosti, koji nadmašuje granice lokalnog, kako bi se razumjela njena fenomenologija.

\section{Neusklađenost obrazovnog sistema i tržišta rada}

Postojeće stanje u BiH vezano za usklađenost između obrazovnog sistema koji proizvodi kadrove i potražnje na tržištu rada okarakterisano je nezadovoljavajućim u više analiza tržišta rada (npr. Analiza politika u oblasti povezanosti obrazovnog sistema i tržišta rada u Bosni i Hercegovini, 2011.). Nepostojanje adekvatnih mehanizama koji prosljeđuju informacije sa tržišta rada o ponudi i potražnji radne snage mehanizmima za kreiranje politike obrazovanja, prepoznaje se kao jedan od ključnih problema. Posljedice toga su ozbiljne i dugoročne, a najprije se prepoznaju u deficitarnosti određenih zanimanja(npr.zanatskihzanimanja,nekih srednjoškolskih stručnihzanimanja, poput: veterinarski tehničar ili tehničar elektronske optike, ili zanimanja sa visokom i višom spremom, kao što su: inžinjer geotehnike, diplomirani farmaceut, diplomirani grafički inžinjer) paralelno uz kontinuirano povećanje produkcije drugih zanimanja, koje zbog prekobrojnosti kadrova iz te oblasti vodi samo povećanju broja registrovanih na zavodima za zapošljavanje. Visoka stopa nezaposlenosti povezana je sa maladaptacijama na domaćem tržištu, koje se očituju i u fenomenu prekomjernog obrazovanja (engl. overeducation). Uz prekomjerno obrazovanje najčešće se pominje i fenomen nedovoljnog obrazovanja (engl. undereducation). CPU studija ${ }^{2}$ (2011) tržišta rada u $\mathrm{BiH}$ identificirala je oba ova fenomena kao vrlo čestu pojavu u $\mathrm{BiH}$. I dok se pod prekomjernim obrazovanjem podrazumijeva da nezaposlene osobe prihvataju poslove koji su ispod njihovih stečenih kvalifikacija, nedovoljno obrazovanje indicira nedostatak kadrova sa znanjima potrebnim za obavljanje određenih poslova. I u jednom i u drugom slučaju dolazi do

2 CPU- Centar za politike i upravljanje. Analiza politika u oblasti povezanosti obrazovnog sistema i tržišta rada u Bosni i Hercegovini, april, 2011. 
povećanja troškova: u prvom slučaju zbog rasipanja sredstava na obrazovanje ovih kadrova, a u drugom slučaju zbog angažovanja ili uvoza deficitarnih kadrova.

Percepcija ovakvog stanja na tržištu rada, a posebno o poželjnosti ili nepoželjnosti određenih profila zanimanja, kod zaposlenih ili onih koji će to tek postati, može voditi kreiranju anticipacija o njihovoj zapošljivosti u budućnosti. Takva anticipacija, posebno kod zaposlenih, vjerovatno će posredovati u njihovim reakcijama na eventualni doživljaj nesigurnosti posla. Naime, osobe koje svoje zanimanje prepoznaju među deficitarnim zanimanjima na tržištu rada mogu razviti pozitivniji stav prema budućnosti čak i u uslovima nedovoljne sigurnosti zaposlenja na trenutačnom poslu. Reakcije na doživljenu nesigurnost posla tada bi mogle biti mnogo umjerenije nego kod osoba koje svoje zanimanje procjenjuju manje atraktivnim na tržištu rada.

\section{Mladi i nesigurnost posla}

Ispitivanje opravdanosti pretpostavke o postojanju dobnih razlika u doživljaju nesigurnosti posla je u brojnim istraživanjima rezultiralo nalazom koji sugeriše da razlike postoje, kao i da su mlađe osobe nesigurnije u izvjesnost svoga posla u budućnosti u odnosu na starije osobe. De Bustillo i De Pedraza (2010) zaključuju kako je nalaz o većoj nesigurnosti u budućnost zaposlenja kod mlađih očekivan s obzirom na to da mladi ljudi obično imaju nesigurnija zaposlenja, više fluktuiraju s posla, a stopa njihove nezaposlenosti je viša. Nalaz o doživljaju veće nesigurnosti posla kod mlađih osoba u skladu je sa rezultatima do kojih su u svojim istraživanjima došli npr. Roskies i Louis-Guerin, 1990., kao i Sverke i sar., 2004. (prema Maslić Seršić i Trkulja, 2009). Rezultat koji sugeriše veću nesigurnost posla kod mlađih osoba može se tumačiti iz nekoliko perspektiva.

Najprije, važno je podsjetiti kako su se u posljednjih nekoliko decenija desile znakovite promjene u načinu života koji mladi ljudi vode. Tržište rada je postalo generalno nesigurnije, a obrasci i pristupi obrazovanju kao i obrasci porodica (sve veći broj nepotpunih porodica, vanbračnih porodica, samačkih domaćinstava, itd.) su se mijenjali i dalje se značajno mijenjaju. I dok su generacije ovih mladih osoba odrastale u sistemu vrijednosti, koji je njihovim roditeljima omogućavao relativno sigurno zaposlenje, skoro pa zagarantovano samim ulaskom u neku radnu organizaciju (MacDonald, 1999), danas se mladi suočavaju sa sasvim novim uslovima i politikama zapošljavanja, koje u najmanju ruku odražavaju generalnu nesigurnost i neizvjesnost. 
Sliku svog položaja na tržištu rada, determiniranu objektivnim okolnostima povezanim sa globalnim kretanjima na tržištu rada (npr. svjetska ekonomska kriza) dodatno usložnjava specifični ekonomsko-politički kontekst našeg geografskog područja. Opažena visoka stopa nezaposlenosti u $\mathrm{BiH}$, koja se dobrim dijelom oslikava i kroz nezaposlenost mladih osoba, posebno bi mogla doprinijeti razvoju osjećaja nesigurnosti među mladim zaposlenicima. I pored samopouzdanja proizašlog iz posjedovanja savremenih saznanja iz određenih relevantnih oblasti kao i kompetencija stečenih uglavnom tokom obrazovanja (koje bi trebale doprinijeti razvoju osjećaja kompetentnosti kod mladih ljudi), nedostatak prakse tokom obrazovanja, relativno malo radno iskustvo ili nepostojanje radnog iskustva mogli bi mlade osobe staviti u nepovoljniji položaj u odnosu na starije, uglavnom iskusnije kolege. Pokazatelji analize trendova na tržištu rada kod nas (npr. Funkcionalni pregled tržišta rada u $\mathrm{BiH}$, EU CARDs, 2005, prema CPU, 2011), ali i u svijetu (MacDonald, 1999) upućuju na zaključak o tome da se mladi ljudi duže zadržavaju u obrazovanju, što vodi prevelikoj produkciji osoba sa visokoškolskim obrazovanjem. Percepcija ovakvih trendova od strane mladih ljudi može voditi stvaranju dojma o postojanju velike konkurencije među mladim zaposlenicima, a koja se prepoznaje kao potencijalni ugrožavatelj njihove prilike za zadržavanje trenutnog posla ili pronalaska novog u slučaju da izgube trenutno zaposlenje. Ovakve evaluacije dodatno mogu opteretiti predvidivost statusa na tržištu rada i razvijati osjećaj nesigurnosti posla. Autori ističu da mlade osobe pokazuju nesigurnost $\mathrm{u}$ intervjuima za posao, stoga bi njihova nesigurnost mogla biti povezana sa anticipacijom lošeg uspjeha u traženju novog posla, nakon što bi ostali bez trenutnog posla. Čini se da intervju za posao predstavlja onaj aspekt procesa traženja posla zbog kojeg mlade osobe osjećaju najveću neprijatnost. Nasuprot njima, starije kolege imaju duže radno iskustvo (imajući u vidu godine starosti), te s obzirom na to bolje pretpostavke za razvoj samopouzdanja kroz iskustvo komunikacije sa drugim ljudima u radnom procesu, a koje bi moglo doći do izražaja pri traženju novog posla. Kuhnert i Vance (1992, prema Cheng i Chan, 2008) ističu kako se razlike u rekacijama na doživljenu nesigurnost posla između mlađih i starijih zaposlenika mogu pripisati razlikama u njihovim stavovima prema poslu. De Witte (1999, prema Cheng i Chan, 2008) sugeriše u svojim analizama kako stariji zaposlenici gubitak posla mogu doživjeti tek kao prijevremeno penzionisanje, te stoga mogu doživjeti manje ozbiljnom nesigurnost posla nego mlađe osobe. Na sličan način bismo mogli pretpostaviti kako će upravo zbog razlika u stavovima prema poslu i anticipacije posljedica nastalih usljed 
eventualnog gubitka zaposlenja mlađi zaposlenici prije svoj posao doživjeti nesigurnim nego stariji zaposlenici, a nakon toga razviti i snažnije reakcije na tako doživljenu neizvjesnost svoga zaposlenja u budućnosti.

Razloge za veću opaženu nesigurnost posla među mlađim zaposlenim osobama možemo tražiti i u specifičnostima razvojnog perioda koji prate određeni razvojni zadaci, socijalna i emocionalna iskustva. Iako se mlađa odrasla dob uvriježeno percipira kao vrijeme ispunjeno različitim mogućnostima i prilikom za avanturističko preispitivanje života, mladi ljudi koji su već kročili na tržište rada napuštaju neke ranije obrasce ponašanja i preuzimaju nove uloge i obaveze. Prema teoriji razvoja odraslih Daniela Levinsona (1978, prema Schaie i Willis, 2001), ,početnički stadij,, rane odrasle dobi obilježen je sa četiri glavna zadatka, od kojih se tri odnose na karijeru osobe: izbor zanimanja, oblikovanje „Sna,, i nalaženje mentora. San predstavlja viziju života koju mlada osoba ima, a što uključuje i obrasce porodičnog života i životne okoline, ali za većinu ljudi središnja slika tog „Sna, jeste slika zanimanja. Preispitivanje napravljenog izbora zanimanja, kao i suočavaje sa posljedicama tog izbora nastavlja se i nakon stupanja na tržište rada i prvih radnih iskustava. Pod pretpostavkom da je odabrao željeno zanimanje i posao mladi čovjek se suočava sa problemima ,rane profesionalne socijalizacije,, koja se odnosi na kreiranje očekivanja u odnosu na posao koji se obavlja, pitanja slaganja sa saradnicima na poslu, od kojih se neki ponašaju i neprijateljski i suparnički, postavljanja prema autoritetu, zaštite vlastitih interesa i sl. (Schaie i Willis, 2001). Nejasnoća u radnoj situaciji koja proizlazi iz ovakvih dilema kod mladih ljudi bi posebno mogla utjecati na manjak pouzdanja u strukturiranost i predvidivost radne situacije, vlastiti status u radnoj organizaciji, a time i razvoj osjećaja nesigurnosti posla.

U prilog činjenici da mlađa odrasla dob predstavlja emotivno bremenit period života koji zbog specifičnosti ovog razdoblja može voditi pojačanom doživljaju nesigurnosti posla govori i Robinson (2011). Autor ističe kako ovaj period života, koji naziva ,krizom četvrtine životne dobi,, (engl.,,quarterlife crisis,,), obilježava borba s anksioznošću povezanom sa nesigurnošću posla, nezaposlenošću, dugovima, partnerskim ili prijateljskim vezama, a obuhvata dvadesete i tridesete godine života. U jednom istraživanju koje je proveo Robinson (2011), 86\% od ukupno 1100 mladih ljudi izvještavalo je o tome da osjećaju kako se nalaze pod pritiskom da budu uspješni u svojim vezama, finansijama i poslovima prije 30. godine života. Robinsonova relativno nova koncepcija krize četvrtine životne dobi svoje temelje ima u poznatim koncepcijama razvojnih kriza Erika Eriksona (1968, prema Robinson, 2011) i Danijela Levinsona (1978. ili 1985, prema Robinson, 2011). Pridavanje 
značaja postojanju pritiska koji mladi osjećaju zbog očekivanja koja okolina postavlja pred njih, Robinsonovu krizu četvrtine životne dobi čini također bliskom teoriji socijalnog sata, koju je predložila Neugarten (1977, prema Bertrand i Lachman, 2003). Ona je pretpostavila da će se razvoj tokom života odvijati na vrijeme ili prerano odnosno prekasno u odnosu na kulturološke norme (npr. kulturološka očekivanja u odnosu na vrijeme stupanja u brak, zapošljavanja, obezbjeđivanje stabilnih i kontinuiranih prihoda, rođenja prvog djeteta itd.). Rezultati istraživanja koja su proveli Helson i sar. (Helson i sar., 1984; Helson i Moane, 1987; Helson i Wink, 1992; Mitchell i Helson, 1990, prema Bertrand i Lachman, 2003) ilustriraju kako socijalni sat služi kao barometar u odnosu na koji pojedinac evaluira svoj uspjeh u životu. Sa pravovremenim izvršenjem obaveza i preuzimanjem uloga, pojedinac priskrbljuje socijalno odobravanje i razvija pozitivna osjećanja proistekla iz doživljaja usklađenosti vlastitih životnih iskustava sa očekivanjima koja društvo stavlja pred njega/nju. U suprotnom, osoba ostaje bez socijalne podrške, a doživljaj nekongruentnosti između društvenih očekivanja i ličnog iskustva doprinosi tome da događaji poput stupanja u brak, zapošljavanja i sl. postaju mnogo stresniji za pojedinca. U kontekstu ove teorije, socijalni sat „otkucava,, kao i vrijeme potrebno za pronalazak zaposlenja i obezbjeđivanje relativno stabilnih prihoda, stavljajući pred mlade ljude vrlo težak zadatak: pronaći i zadržati stabilan, siguran posao. Doživljaj o postojanju sveprisutnog pritiska, osjećánja razočarenja, usamljenosti, pa čak i depresije i opšte nesigurnosti, koji se najčešće vežu uz ovaj period života, mogli bi biti itekako odgovorni za razvoj osjećaja veće nesigurnosti posla kod mlađih osoba, s obzirom na specifičnosti ovog razvojnog perioda.

\section{Odgovornost za izvjesnost u zapošljavanju i zapošljivost mladih na tržištu rada}

Borba protiv nezaposlenosti i nezapošljivosti trebalo bi da se vodi još za vrijeme formalnog obrazovanja.

Dva su ključna problema koja se često stavljaju u fokus rasprava o nepovoljnim okolnostima zbog kojih mladi ne uspijevaju na tržištu rada biti ono što su prvobitno zamislili, ili ono što su njihovi potencijali, aktualizirani u konkretnom radnom kontekstu, mogli ponuditi svijetu rada.

To su:

- Neusklađenost obrazovnog sistema i tržišta rada,

- Nedovoljna usmjerenost obrazovnog sistema na sticanje kompetencija važnih za tržište rada. 
No ovo nisu jedini razlozi nepovoljne situacije na tržištu rada. Odgovornost se za ovakve nepovoljne okolnosti nesigurnosti nekada neopravdano dijeli samo između ova dva argumenta. Pitanje je: šta je sa individualnom odgovornosti pojedinca koji traži svoju ulaznicu za tržište rada? Gdje je u svemu tome odgovornost poslodavaca u kreiranju povoljnog okruženja za učenje na radu?

Još uvijek traje, i sve su prilike da će se još neko vrijeme osjećati, polemika oko toga ko se treba držati odgovornim za to što mladi ljudi nakon izlaska iz obrazovnih instituacija nemaju ključne kompetencije za obavljanje posla. Kao i mnoga druga pitanja, i ovo nudi barem dvije istine koje se međusobno ne isključuju već nadopunjavaju. Okosnica ove rasprave jeste pitanje odgovornosti. Da li je odgovoran obrazovni sistem? Da li su odgovorne strukture vlasti koje kroje upisnu politiku u obrazovnim institucijama? Da li odgovornost pripada pojedincu? Ovo pitanje je već dobilo nagovještaj svoga odgovora u prethodno istaknutom problemu ponekad vrlo naglašene disfunkcionalne komunikacije obrazovnog sistema/politika i tržišta rada. No, koliko je obrazovni sistem, gledajući u širem kontekstu zaista odgovoran?

Jedna od istaknutih uloga obrazovanja jeste osposobljavanje čovjeka za samostalan i produktivan rad koji u svojoj konačnici treba ispunjavati više značajnih psiholoških funkcija. Očekivanja mladih ljudi da će u obrazovnim institucijama dobiti sva znanja i razviti sve vještine koje će moći uspješno primijeniti na svom radnom mjestu su pogrešna pretpostavka na kojoj se, nažalost, bazira neosnovan optimizam mladog i neiskusnog pojedinca. A upravo će iskustvo posvjedočiti tome da je obrazovanje temelj za sticanje navike usmjerenog $\mathrm{i}$ kompetentnog načina razmišljanja koje će nas voditi kroz procese profesionalnog sazrijevanja. Na tom putu, znanja i vještine stečeni tokom formalnog obrazovanja predstavljaju značajnog partnera u procesu sticanja kompetencija za rad. Oni su tek poligon na kojem će se utiskivati radna iskustva, koja se, kao što i sama riječ kaže, stiču samo i jedino radom.

\section{Uloga poslodavaca u smanjenju nesigurnosti posla}

Osigurati produktivno radno okruženje sa stalno potvrđujućom spremnošću za kontinuirano prilagođavanje izazovima na lokalnom i globalnom tržištu veliki je zadatak voditelja radnih grupa i organizacija. Sinhronizacija pulsa organizacije koja živi (preživljava) sa adrenalinskim šokovima što u vidu novih tehnoloških, kompetencijskih i finansijskih izazova prispijevaju sa globalog tržišta, ponekad je veoma teška i neizvjesna. Da li će ,pacijent, preživjeti, pokazuje se, zavisit će pored ostalog i od privrženosti zaposlenika 
koji tu rade. Njihova spremnost da i u uslovima koji nisu optimalni (nerijetko suboptimalni) ulažu napor u postizanje dobrih radnih rezultata $\mathrm{i}$ poslovne izvrsnosti odredit će, dugoročno gledajući, put radne organizacije: preživljavanje ili postepeni pad u nepovrat.

Sasvim je jasno kako nesigurnost posla i neizvjesno radno okruženje predstavljaju bolnu prepreku na putu realizacije ove privrženosti. Zaposlenik koji ima sliku u kojoj poslodavac ne može ili neće (u nekom momentu razlikovanje ove dvije kategorije postaje irelevantno) obezbijediti izvjesnost zaposlenja u budućnosti, spreman je takvu situaciju procijeniti ugrožavajućom. Percepcija ugroženosti i, nerijetko, nekontrolabilnosti ishoda vodi pogoršanju stavova prema poslu i najčešće smanjenju radne učinkovitosti. Ovakvi nalazi jasno potcrtavaju zbog čega bi brigom o tome koliko se njihovi zaposlenici osjećaju nesigurno trebali biti bremeniti radni sastanci menadžementa organizacije, a strategijama suočavanja sa nesigurnošću zaposlenja strateški planovi razvoja. Tamo gdje je još uvijek uvriježeno uvjerenje da je priča o stavovima zaposlenika prema poslu, njihovoj privrženosti radnoj organizaciji tek puko opravdanje za postojanje HR-odjela ${ }^{3}$ potrebno je sprovesti logičnu persuaziju. Ubjeđivanje u suprotno od tog mišljenja ili persuazivno djelovanje s ciljem osvještavanja o značaju ljudskih resursa i njihovih osjećaja ponekad može biti vrlo jednostavno: predočiti razlike u tome kakve posljedice na rad može imati siguran a kakve nesiguran zaposlenik u svom radnom okruženju.

Privrženi zaposlenik spreman je drugima pozitivno govoriti o svojoj organizaciji, on želi ostati u njoj i spreman je uložiti velik napor u postizanju njenih poslovnih ciljeva. Percipirana nesigurnost posla može imati značajan negativan efekat na prethodno pomenuta ponašanja. Zaposlenik će u ovakvim okolnostima pokušati naći novi posao, širiti negativnu sliku o organizaciji i smanjiti ulaganje napora u radu. Nespremnost da prihvati ovakvo radno okruženje posljedično može dovesi i do (ne)kritičkog promišljanja odluka koje donosi menadžment organizacije. To će se najprije ogledati u osjećaju naglašenog negativizma spram donesenih odluka, osjećaju nepovjerenja u iskrenost u komunikaciji i želje menadžmenta da se aktivno pozabavi stanjem i pronađe najbolje strategije suočavanja sa nastalom situacijom. Sve ovo vodi bazičnom nepovjerenju zaposlenih i smanjenju njihove privrženosti.

No, ukoliko menadžment radne organizacije ne pravi ovakve pogreške i istinski želi pronaći puteve ka aktivnom suočavanju sa problemom

3 HR - engl. Human Resource - ljudski resursi; HR-odjeli: u strukturi radnih organizacija to su odjeli koji se bave upravljanjem ljudskim resursima te radne organizacije (kroz, npr., upravljanje radnim učinkom zaposlenih, ispitivanje obrazovnih potreba i realizaciju obuke i treninga zaposlenih, osmišljavanje strategija motiviranja zaposlenih za rad, itd.). 
nesigurnosti radnog okruženja nameće se pitanje: Postoji li nada za to da u radnim organizacijama i uslovima finansijske nemoći postoje načini motiviranja zaposlenika da ostanu na svojim radnim mjestima i kvalitetno rade?

Za one rukovodne stukture koje to zaista žele znati i postići, važna je spoznaja kako postoje finansijski neopterećujući načini osiguravanja privrženosti zaposlenika u uslovima nesigurnosti. Jedan od ključnih jeste osiguranje proaktivne komunikacije koja sprečava širenje glasina i omogućava pravovremenost u plasiranju važnih informacija zaposlenicima, kako dobrih tako loših. Vrlo je važno da menadžment održava imidž dostupnosti, i u skladu sa svojim primarnim radnim odgovornostima ali i razinama u organizacijskoj hijerarhiji odgovara na dileme i zabrinutost zaposlenika u vezi sa značajnim pitanjima. Usklađenost u govoru i djelovanju i konzistentnost u sprovedbi donesenih odluka stvorit će osjećaj da je situacija pod kontrolom i da se mogu očekivati pozitivne promjene. No, aktivno suočavanje menadžementa sa neizvjesnošću i nesigurnosti radnih mjesta ogleda se i u nastojanju da se kod zaposlenih razvija osjećaj osnaženosti da se vlastitim kapacitetima nose sa nesigurnošću. Tu pitanje obrazovanja na radnom mestu i sticanje kompetencija posebno ima smisla.

\section{Obrazovanje i obučavanje u radnim organizacijama}

Organizacije, koje su shvatile da bez kontinuiranog i planskog razvoja ljudskih potencijala neće biti moguće odgovoriti na promjenjive zahtjeve na tržištu rada, obrazovanje i obuku zaposlenih uklopili su u funkciju upravljanja ljudskim resursima. Ona se uglavnom odvija unutar organizacije, ali i izvan nje. Neke od njih rješenja za svoje obrazovne potrebe pronalaze i u organizaciji internih škola ili profitnih centara, odnosno preduzeća. Njihova se funkcija ogleda u obezbjeđivanju potrebnih znanja i vještina za zaposlene u samoj organizaciji ili izvan nje (Vujić, 2003). Ove organizacije su donijele odluku da će na sve promjenjivije i manje predvidive zahtjeve tržišta odgovarati na jedino mogući način: adaptivno - manifestirajući svoju fleksibilnost i prilagodljivost kako u rukovođenju i upravljanju tako i u kontekstu obezbjeđivanja uslova za sticanje kompetencija (zaposlenika) potrebnih za opstanak u punom smislu te riječi. Opstanak u ovom kontekstu posebno naglašava činjenicu da obrazovanje i obuka trebaju obezbijediti prevazilaženje tzv. „skill-gapa,, - diskrepancije između kompetencija koje zaposlenici imaju i upošljavaju u radu i onih kojima bi trebalo da teže, koje su im potrebne kako bi uspješno odgovorili na nove zahtjeve posla. 
Odlučiti da su obrazovanje i obuka dobra strategija za postizanje poslovne izvrsnosti i obezbjeđivanje poslovnih rezultata nije jedina odluka koju treba donijeti. Rukovodstvo organizacije mora strateški razmišljati, a to, između ostalog, znači prepoznati potrebe zaposlenika za određenom vrstom obrazovanja i obučavanja, a zatim napraviti plan obrazovanja i obučavanja. To između ostalog znači analizirati potrebe zaposlenika za vrstom obrazovanja i obuke, ocijeniti koje su kompetencije i na kojim poslovima (radnim mjestima) ključne za postizanje željenih rezultata, identificirati polaznike, predavače itd.

No, zabrinutost koja često proizlazi iz planiranja i prakse obrazovanja zaposlenih mogla bi biti kamen spoticanja u provedbi plana obrazovanja zaposlenih u funkciji povećanja njihove zapošljivosti. I ona je, na prvu, skoro pa dobrim dijelom opravdana. Zapravo, poslodavci se nerijetko suočavaju sa vrlo nezgodnom praksom u kojoj se prvobitna ulaganja u ljudski potencijal pokažu kao trošak. To se dešava u situacijama kada se ulažu sredstva u obuku zaposlenika za osposobljavanje za rad nakon čega neki zaposlenici odluče napustiti radnu organizaciju i potražiti novo radno mjesto i novog poslodavca. Odluku o napuštanju radne organizacije zaposlenici temelje na potrebi i želji da pronađu za sebe adekvatnije radno okruženje (ponekad je to ono koje omogućava bolje prihode, beneficije zaposlenicima, rad na savremenijim tehnologijama, manje stresno radno okruženje itd.). Pri tome, oni osjećaju veće profesionalno samopouzdanje, koje duguju svom prethodnom poslodavcu. Neki poslodavci nastoje sačuvati svoj kadar obavezujući ga da ostane u organizaciji određeno vrijeme (npr. tri godine) nakon što su prošli određenu edukaciji na trošak organizacije. Tamo gdje to nije praksa, problemi sa isplativošću ulaganja ovog tipa mogu biti prilično problematični.

\section{Uloga psihologa u obrazovanju i obuci zaposlenih}

Prenošenje stručnog znanja neophodog za rad, uvježbavanje motoričkih radnji za efikasno obavljanje posla koje treba biti brzo, tačno i sigurno predstavljalo je nekada okosnicu obučavanja i obrazovanja zaposlenih (Vujić, 2003). To se i dalje pokazuje kao vrlo važno, ali novi zahtjevi pred obukom i obrazovanjem su daleko veći. Danas se izuzetno vodi računa da obrazovanje u radnoj organizaciji ne bude pretjerano generalno, ciljno neizdiferencirano i samo sebi svrha. U takvom nastojanju, između ostalog, posebno je prepoznatljiva uloga psihologa.

$\mathrm{Na}$ putu postizanja ekonomske efikasnosti i kvalitetnog rada, uloga psihologa je značajna. Danas kada cilj obrazovanja i obučavanja seže mnogo dalje od osposobljavanja zaposlenih za rad i usvajanja vještina, psiholozi 
nose dio odgovornosti za obezbjeđivanje konteksta u kojem će zaposleni biti sve više osposobljeni da razmišljaju, rješavaju probleme u skladu sa ciljevima organizacije. Njihovo radno ponašanje treba odražavati saradljivost, spremost za prihvatanje odgovornosti, toleranciju na stres. Imajući to u vidu, psiholozi u radnim organizacijama, u saradnji sa drugim andragoškim djelatnicama unutar i izvan organizacije, nastoje dio svoje radne prakse posvetiti obuci zaposlenih iz oblasti: socijalne percepcije, komunikacije u radnim organizacijama, konstruktivnog rješavanja konflikta, timskog rada, upravljanja stresom i stilova rukovođenja, motivacije itd. Rezultati analiza zadovoljstva polaznika ovakvim treninzima sugerišu da su zaposlenicima potrebne i ove kompetencije koje izlaze izvan okvira stručnih kompetencija vezanih za radno mjesto. One ih čine samopouzdanijim u ulogama koje imaju na poslu, a nerijetko se odražavaju i na cjelokupnu dobrobit pojedinca koja se reflektira i na privatnu sferu života.

Pored ostalih, značajna uloga psihologa se prepoznaje i u savjetovanju zaposlenika pri zapošljavanju, uvođenju u posao (to se posebno odnosi na mlađe zaposlenike) ali i u nošenju sa uslovima neizvjesnosti zaposlenja. Pri tome, isticanje važnosti preuzimanja individualne odgovornosti zaposlenika za vlastitu zapošljivost trebala bi biti jedna od važnijih poruka koju psiholog šalje zaposleniku.

\section{Zaposlenici preuzimaju odgovornost za vlastitu zapošljivost}

Pitanje opstanka na trenutnom radnom mjestu nije uvijek ključno i ono koje generira najveću razinu anksioznosti. U uslovima života koje sve više karakteriše kontinuirani porast troškova života, stanarine, cijene potrošačke korpe, praćenih restrikcijama u državnim budžetima, bitno je „,biti zaposlen,,. Zabrinutost $u$ vezi sa osiguranjem statusa zaposlenosti nadvisuje zabrinutost u vezi sa zadržavajnem konkretnog posla. Na putu ostvarenja tog cilja stoji potencijal za sticanjem kompetencija koje mogu skoro pa univerzalno biti primjenjive na istim ili sličnim radnim mjestima. Takva snaga koja leži u posjedovanju generičkih kompetencija osigurava veću zapošljivost zaposlenika i osnažuje njihovo samopouzdanje u vezi s tim da će, ukoliko izgube trenutni posao, imati veću šansu da pronađu novi posao.

Uloga organizacije, kako je već naznačeno, ovdje može biti vrlo važna. Nastojeći u svoje programe brige o zaposlenim u uslovima neizvjesnosti radnog okruženja unijeti i trening ili edukaciju iz ovladavanja (određenim) generičkim kompetencijama, organizacija postiže više ciljeva. Najočigledniji jeste obuka i usavršavanje zaposlenika za rad, a posredno sve to ima značajan 
psihološki efekat. On se ogleda u tome da zaposlenici stiču dojam o tome da je organizaciji stalo do njih i da brine o svojim zaposlenim. Takav stav povećava vjerovatnost za to da će zaposlenici zadržati ili intenzivnije osjećati privrženost organizaciji. Kao posljedica, ovo nerijetko vodi oblikovanju i drugih pozitivnih stavova prema organizaciji, te pozitivnih oblika radnog ponašanja, poput ulaganja većeg napora u obavljanje svakodnevnih radnih aktivnosti.

No, realnost je takva da će organizacije biti sve manje spremne obećavati sigurnost zaposlenja, a značajna se promjena ogleda i u tome da će pojedinac sve više i u sve većem obimu sam snositi odgovornost za izvjesnost svog zaposlenja u budućnosti. I dok će stremljenje ka očuvanju zaposlenja u okviru jedne organizacije postati stvar prošlosti, borba za sticanje ili očuvanje „zapošljivosti,, na tršištu rada postati će glavno oruđe u rukama zaposlenika koji se aktivno nose sa neizvjesnošću koju budućnost sobom nosi. S obzirom da će planiranje zaposlenja i karijere u budućnosti postati vrlo težak zadatak, jedino sa čim zaposlenik može računati jeste rad na vlastitom usavršavanju, briga o tome da svojim kompetencijama adekvatno odgovara na sve izazovnije standarde izvrsnosti u radu, pravovremeno donosi dobre poslovne odluke, brine se sam o postizanju zadovoljstva poslom itd. (Kiechel, 1987: 81, prema Jacobson i Hartley, 1991). Ovakve okolnosti trebaju biti naznačene mladima još u periodu njihovog formalnog obrazovanja ali i kasnijeg profesionalnog usavršavanja. Globalno ozračje nesigurnosti i vrlo ubrzana dinamika promjena na tržištu rada samo pojačavaju osjećaj kako doživljaj individualne odgovornosti za vlastitu budućnost treba preuzeti primat $\mathrm{u}$ upravljanju individualnim akcijama ljudi. Vjerovatno se jedino na ovaj način može izbjeći nefunkcionalna infantilizacija zaposlenih koja od ljudi pravi pasivne konzumente (ne)prilika i žrtve, za čiji se nepovoljan položaj okrivljuju vanjski nekontrolabilni faktori (npr. globalno loša slika svjetske ekonomije, loše rukovođenje, nezainteresirani šefovi itd.). 


\section{Zaključak}

Formalno obrazovanje mladih zaposlenika često završava prije prvog stupanja u radni odnos. Neki tom činjenicom bivaju ohrabreni, vjerujući da je došlo vrijeme da stečena znanja i vještine ,oprobaju, u praksi, nakon godina školovanja i uloženog truda. No, bosanskohercegovačka realnost nerijetko tek tada naglasi koliko je kontinuirano ulaganje u obrazovanje važno i nakon završetka formalnog obrazovanja i sticanja željenog zvanja. I to na najmanje tri načina:

- kada mladi ljudi shvate da tržište rada traži druga zanimanja, te u nastavku obrazovanja vide svoje šanse za pronalazak zaposlenja;

- kada na svom radnom mjestu vide da je ulaganje u znanje i vještine vjerovatno jedan od najboljih načina aktivnog nošenja sa neizvjesnim radnim okolnostima;

- kada opaze da radni trendovi postavljaju sve veće zahtjeve za povećanjem i obima i kvalitete kompetencija zaposlenih, pri čemu ih ujedno obavezuju na kontinuirano usavršavanje.

Jasno je da se kod nekih pojedinaca motivacija za nastavak obrazovanja oblikuje oko jednog, dva, a kod nekih i oko sva tri navedena načina razmišljanja.

Visoka stopa nezaposlenosti, niska stopa aktivnosti, neusklađenost ponude i potražnje za radnom snagom, kao i niska mobilnost radne snage predstavljaju osnovne karakteristike tržišta rada u $\mathrm{BiH}$, prema rezultatima studije CPU-a (Centar za politike i upravljanje) od aprila 2011. godine. Kao značajne antecedencije ovakvog stanja na tržištu rada u $\mathrm{BiH}$, studija ističe zabrinjavajući trend smanjenja radno sposobnog stanovništva (nastao kao rezultat smanjenja prirodnog priraštaja i migracije), neadekvatnu ponudu radne snage kao i neusklađenost ili nepovezanost obrazovnog sistema i tržišta rada. Percepcija ovakve nepovoljne slike na tržištu rada suprotstavlja se tendencijama optimističnog gledanja u budućnost zapošljavanja mladog kadra. No, umjesto da ovakvo stanje generira pesimizam i pasivan odnos prema okruženju, ono treba pozvati na preuzimanje odgovornosti za uvođenje konstruktivnih promjena. U tom smislu, posebno se ističe uloga kreatora obrazovnih politika, tržišta rada i poslodavaca.

Prilagođavanje sve promjenjivijim i nepredvidljivijim radnim uslovima, koje karakteriše povećana nesigurnost posla nije i ne smije biti isključiva obaveza pomenutih struktura, već i svih zapolenika. Povećanje svijesti o tome da će neizvjesnost radne situacije vjerovatno rasti s vremenom, a sa njom 
i negativne posljedice, trebalo bi djelovati poticajno u smjeru preuzimanja individualne odgovornosti za vlastitu budućnost. Zaposlenici trebaju biti i te kako svjesni toga i kontinuirano raditi na ažuriranju svojih znanja i vještina u skladu sa anticipacijom novih zahtjeva u budućnosti, gdje fleksibilnost, spontanost i nepredvidivost zauzimaju istaknutu poziciju. Redizajniranje radnih mjesta, sve veća prevalencija ugovora na određeno vrijeme, naglašavaju karakter privremenosti i potrebe za ,preživljavanjem,,, gdje organizacije kao i pojedinci koji žele ostati „u igri,, moraju kontinuirano ulagati napor u povećanje svojih kompetencija i kompetitivnosti na tržištu rada.

\title{
TO CONTINUE EDUCATION WITH DOUBTFUL PROSPECTS - TICKET FOR THE LABOUR MARKET, TICKET FOR THE EMPLOYMENT AGENCY OR A GOOD MANAGEMENT STRATEGY?
}

\begin{abstract}
- Abstract -
One of the, with increased regularity accented, interpretations of the bosnian-herzegovinian context suggests that institutions of higher education and the labour market implement two (inappropriately) separated policies. At the same time, young people try to improve their chances on the labour market through own assessment of risks and possibilities which might emerge if they continue their education. Is this investment (of time, material resources, enthusiasm) really convenient or at least proportional to the value of the expected outcome? It seems that this hypothesis will not be seriously considered before a person faces the (im)possibility of finding a job in her/ his profession or faces the challenge of keeping a job, once she/he entered the labour market
\end{abstract}

Keywords: insecure employment, younger employees, education system, education and training in working organisations. 


\section{Literatura}

- Bertrand, R. M., Lachman, M. E. (2003). Personality Development in adulthood and old age. U Weiner, B., Greedheim, D. K., Lerner, R. M., Easterbrooks, M. A., Schinka, J. A., Mistry J. (Ur.). Handbook of psychology: Developmental pschology (463 - 487). New York: John Wiley \& Sons.

- Cheng, G. H.-L., Chan, D.K.-S. (2008). Who Suffers More from Job insecurity: A Meta-Analytic Review. Applied psychology: An International Review, 57 (2), 272-303.

- CPU- Centar za politiku i upravljanje. Analiza politika u oblasti povezanosti obrazovnog sistema i tržišta rada u Bosni i Hercegovini, april, 2011. Pristupljeno 9.10.2011., $8.00 \mathrm{~h}$ na http://www.cpu.org.ba/ files/CPU $\% 20$ Povezanost $\% 20$ trzista $\% 20 \mathrm{rada} \% 20 \mathrm{i} \% 20$ obrazovanja. pdf.

- De Bustillo, R. M., De Pedraza, P. (2010). Determinants of job insecurity in five European countries. European Journal of Industrial Relations, 16(I), 5-20.

- Jacobson, D., Hartley, J. (1991). Mapping the Context. U Hartley, J. Jacobson, D., Klandermans, B., van Vuuren, T. (Ur.) Job Insecurity: Coping with Jobs at Risk (2-22), London: Sage Publications.

- MacDonald, R. (1999). The road to nowhere: Youth, insecurity and marginal transitions. U Vail, J., Wheelock, J., Hill, M. (Ur.). Insecure times: living with insecurity in contemporary society. New York: Routledge.

- Maslić Seršić, D., Trkulja, J. (2009). Nesigurnost posla kao predmet istraživanja u psihologiji: teorije, operacionalizacije, nalazi. Društvena istraživanja, vol. 8, No 3 (101).

- Robinson, O. C. (Maj, 2011). Quarterlife Crises And Why They Can Be Good For You. British Psychological Society Annual Conference, Glasgow, Scotland

- Schaie, K. W., i Willis, S. L. (2001). Psihologija odrasle dobi $i$ starenja. Jastrebarsko: Naklada Slap.

- Šverko, B. (1991). Značenje rada u životu pojedinca: radne vrijednosti, važnost rada i alijenacija. Uvod u psihologiju, 15-56. Zagreb: Prosvjeta.

- Vujić, D. (2003). Obrazovanje i obučavanje. U Čizmić, S., Kondić, V. (Ur.). Priručnik: Psihologija rada u formuli uspeha organizacije (43-63), Beograd: Centar za primenjenu psihologiju. 